І. Г. Капелька, С. Ю. Штриголь

\title{
Скринінгове дослідження фригопротекторних властивостей нестероїдних протизапальних препаратів за гострого загального охолодження
}

\author{
Національний фармацевтичний університет, м. Харків
}

Ключові слова: холодова травма, гіпотермія, нестероїдні протизапальні препарати

Вплив холоду на організм людини може призводити до тяжких травм переохолодження, замерзання, відморожень. В Україні холодові травми (XT) $€$ досить частим явищем. Вони виникають частіше в зимовий час, коли кількість постраждалих сягає понад 12000 осіб. ХТ спостерігається переважно в молодих осіб працездатного віку, супроводжується великим відсотком інвалідизації та матеріальних витрат на лікування потерпілих. Більшій частині постраждалих необхідне стаціонарне лікування, смертність перевищує $10 \%$. Середня тривалість лікування пацієнтів з ХT у 2 рази вища за тривалість лікування пацієнтів з опіками. Холодові ураження виникають внаслідок порушень мікроциркуляції, особливо на тлі судинних захворювань кінцівок, втоми або стресової ситуації, алкогольного сп'яніння. Особливо небезпечною ХT $€$ в умовах війни. Навіть у сучасних арміях ХT може стати причиною до $25 \%$ санітарних втрат [1-3].

Вплив низької температури ініціюе складний механізм адаптації організму, що спрямований на зниження втрат тепла. Зокрема, спостерігається звуження периферичних судин, збільшення частоти серцевих скорочень, підвищення тиску та, як результат, централізація кровообігу. Це відбувається переважно за рахунок активації симпатоадреналової системи, відповідальної за розвиток стрес-реакції. У разі падіння температури тіла нижче ніж $10{ }^{\circ} \mathrm{C}$ спостерігається парадоксальна реакція Льюїса, що полягає в почерговій зміні

(c) Колектив авторів, 2019 актів вазоконстрикції та вазодилатації тривалістю 5-10 хв і, вочевидь, спрямована на протидію прогресуючій ішемії периферичних тканин. Значну роль у патогенезі XT відіграють продукти метаболізму арахідонової кислоти, а саме: простагландин $\mathrm{F}_{2 \alpha}\left(\mathrm{PGF}_{2 \alpha}\right)$ і тромбоксан $\mathrm{A}_{2}\left(\mathrm{TXA}_{2}\right)$. Вони особливо активно виділяються після завершення реакції Льюїса, посилюючи вазоконстрикцію, агрегацію тромбоцитів та відповідно ішемію, а також беруть участь у розвитку запальної реакції. Крім того, збільшується утворення простацикліну ( $\left.\mathrm{PGI}_{2}\right)$, який $€$ функціональним антагоністом $\mathrm{PGF}_{2 \alpha}$ і $\mathrm{TXA}_{2}$ і дещо сповільнюе ішемізацію тканини [4-6]. 3 урахуванням механізму розвитку XT можна вважати перспективними фригопротекторами нестероїдні протизапальні препарати (НПЗП), які пригнічують синтез простагландинів. Відомо, що використання ацетилсаліцилової кислоти (АСК) та ібупрофену покращують прогноз лікування XT [5]. Доведено наявність фригопротекторних властивостей у целекоксибу та мелоксикаму $[1,7]$. Проте широкі порівняльні дослідження фригопротекторної дії НПЗП за єдиною методикою не проводилися, що залишає відкритим питання вибору найактивніших препаратів. Невідомо, чи має вирішальне значення селективність НПЗП щодо циклооксигенази (ЦОГ). До того ж наявні дані щодо дозозалежності фригопротекторного ефекту НПЗП, зокрема, АСК [3, 8-11], що також потребує вивчення.

Мета дослідження - порівняти виразність фригопротекторного ефекту низки НПЗП з різною селективністю щодо ЦОГ на моделі гострого загального охолодження (ГЗО).

Матеріали та методи. Роботу виконано на білих мишах обох статей масою 
20-24 г (94 особини) протягом одного дня з 12.00 до 18.00 год.

Тварин утримували на стандартному харчовому раціоні віварію за вільного доступу до води, постійної вологості та температурного режиму $+22-23{ }^{\circ} \mathrm{C}$. Протокол дослідження узгоджується 3 біоетичними нормами та відповідає «Загальним етичним принципам експериментів на тваринах" (Україна, 2001 р.), а також не суперечить положенням Європейської конвенції щодо експериментів на тваринах.

Для моделювання ГЗО мишей вміщували до індивідуальних пластикових кліток об'ємом 500 cм $^{3}$ без обмеження доступу до повітря та розташовували в морозильній камері «Nord Inter-300" 3 прозорою кришкою за температури $-18{ }^{\circ} \mathrm{C}$. Інтегральним показником фригопротекторної дії обрано час життя тварин [12].

У дослідженні використовували такі препарати: неселективні інгібітори ЦОГ - АСК (Аспірин, таблетки, «Вауег», Німеччина), ібупрофен (Бруфен, порошок, «Abbott», США), мефенамінова кислота (Мефенамінова кислота-Дарниця, таблетки, «Дарниця», Україна), диклофенак натрію (Вольтарен, таблетки, «Novartis», Швейцарія); помірно селективний інгібітор ЦОГ мелоксикам (Моваліс, таблетки, «Boehringer Ingelheim», Німеччина); високоселективний інгібітор ЦОГ целекоксиб (Целебрекс, таблетки, «Pfizer», США). Таблетки та порошок ібупрофену подрібнювали в ступці та суспендували у воді 3 додаванням твіну-80. Суспензії вводили крізь зонд внутрішньошлунково (в/ш) в об'ємі 10 мл/кг маси тіла (по 0,20-0,24 мл на тварину) у профілактичному режимі за 30 хв до ХT, як рекомендується в дослідженні фригопротекторних властивостей [9]. Тварин випадковим чином розділили на 12 груп, у складі кожної з яких була однакова кількість самців і самок. 1 група - контрольна патологія (XT), $\mathrm{n}=6$ (вводили воду, 10 мл/ кг); 2 група - АCК, 25 мг/кг + ХT (n = 8); 3 група - целекоксиб, 37 мг/кг + $\mathrm{XT}(\mathrm{n}=8) ; 4$ група - целекоксиб, 74 мг/кг + XT (n=8); 5 група - ібупрофен, 100 мг/кг + XT (n = 8); 6 група - ібупрофен, 150 мг/кг + XT $(\mathrm{n}=8)$; 7 група - мелоксикам, 1,4 мг/кг $+\mathrm{XT}$ $(\mathrm{n}=8) ; 8$ група - мелоксикам, 2,8 мг/ кг + XT (n = 8); 9 група -мефенамінова кислота, 46 мг/кг + XT $(\mathrm{n}=8)$; 10 група - мефенамінова кислота, $92 \mathrm{мг/кг} \mathrm{+} \mathrm{XT} \mathrm{(}=8)$; 11 група - диклофенак натрію, 9 мг/кг $+\mathrm{XT}(\mathrm{n}=8)$; 12 група - диклофенак натрію, 18 мг/кг + $\mathrm{XT}(\mathrm{n}=8)$. Дози НПЗП обрано на підставі даних літератури. АСК досліджують як фригопротектор у широкому діапазоні доз - від 15 мг/кг до 250 мг/кг $[3,8,11]$. Проте доза 250 мг/кг виявилась надто високою (токсичною) та неефективною; досить ефективними $\mathrm{\epsilon}$ дози 25-50 мг/кг [3, 8-10]. 3 урахуванням цих даних АСК вводили в дозі 25 мг/кг. Інші препарати досліджено в 2 дозах, які відрізняються в 1,52,0 разу. Їх розраховували, виходячи 3 середніх терапевтичних доз людини 3 використанням рекомендованих FDA коефіцієнтів перерахунку [13].

Для статистичної обробки використовували Т-критерій Стьюдента та дисперсійний аналіз ANOVA у разі нормального розподілу, за його відсутності U-критерій Манна-Вітні та критерій Краскела-Уолліса. Аналіз проводили за допомогою програми Statistica 13.5. Відмінності вважали статистично значущими в разі $\mathrm{p}<0,05$ [14].

Результати та їх обговорення. Результати дослідження наведено в таблиці.

3 поміж неселективних інгібіторів ЦОГ вигідно вирізняються ібупрофен і диклофенак натрію, які статистично значуще збільшили тривалість життя тварин. Ефект ібупрофену виявився помірним за силою та незалежним від дози (100 мг/кг - приріст тривалості життя 34,9\%, 150 мг/кг - 29,8\%). Диклофенак натрію в меншій дозі 9 мг/кг чинив помірну фригопротекторну дію, тенденційно збільшуючи час життя на 27,2 \%, збільшення дози до 14 мг/кг супроводжувалось виразним зростанням ефекту $(54,5 \%, \mathrm{p}<0,01$ щодо контрольної патології). Ефект мефенамінової кислоти в меншій дозі 46 мг/кг не виявлявся, у дворазово збільшеній дозі (92 мг/кг) був нестабільним в окремих тварин $i$, як наслідок, 
Час життя мишей за умов гострої холодової травми

\begin{tabular}{|c|c|c|c|}
\hline Препарат, кількість тварин & $\begin{array}{l}\text { Доза, } \\
\text { мг/кг }\end{array}$ & Час, хв & $\begin{array}{c}\text { Відмінність з показ- } \\
\text { ником контрольної } \\
\text { патології, \% }\end{array}$ \\
\hline \multicolumn{2}{|l|}{ Контрольна патологія (n = 6) } & $53,0 \pm 5,3$ & - \\
\hline \multicolumn{4}{|c|}{ Неселективні інгібітори ЦОГ } \\
\hline Ацетилсаліцилова кислота ( $\mathrm{n}=8)$ & 25 & $60,6 \pm 7,3$ & $+14,3$ \\
\hline \multirow{2}{*}{ Ібупрофен (n = 8) } & 100 & $71,5 \pm 6,1^{*}$ & $+34,9$ \\
\hline & 150 & $68,8 \pm 2,5^{\star}$ & $+29,8$ \\
\hline \multirow{2}{*}{ Мефенамінова кислота $(\mathrm{n}=8)$} & 46 & $53,3 \pm 4,3$ & $+0,6$ \\
\hline & 92 & $68,3 \pm 6,3$ & $+28,9$ \\
\hline \multirow{2}{*}{ Диклофенак натрію ( $\mathrm{n}=8)$} & 9 & $67,4 \pm 5,9$ & $+27,2$ \\
\hline & 14 & $81,9 \pm 3,8^{\star \star / \&}$ & $+54,5$ \\
\hline \multicolumn{4}{|c|}{ Помірно селективний інгібітор ЦОГ-2 } \\
\hline \multirow[t]{2}{*}{ Мелоксикам $(\mathrm{n}=8)$} & 1,4 & $60,3 \pm 7,2$ & $+13,8$ \\
\hline & 2,8 & $67,5 \pm 3,5^{\star}$ & $+27,4$ \\
\hline \multicolumn{4}{|c|}{ Високоселективний інгібітор ЦОГ-2 } \\
\hline \multirow[t]{2}{*}{ Целекоксиб $(\mathrm{n}=8)$} & 37 & $55,4 \pm 1,2$ & $+4,5$ \\
\hline & 74 & $83,1 \pm 2,9^{* \star} / \&$ & $+56,8$ \\
\hline
\end{tabular}

Прилітка. Статистично значущі відмінності: *3 контрольною патологією $(p<0,05)$, ** 3 контрольною патологією $(p<0,01),{ }^{\star} 3$ показникол групи АCK $(p<0,05)$.

хоча й становив у середньому $28,9 \%$, за рахунок значної дисперсії не сягнув достовірного рівня. АСК виявила слабку фригопротекторну активність, тенденційно збільшуючи час життя мишей на $14,3 \%$.

Мелоксикам, який виявляє помірну селективність щодо ЦОГ, у меншій дозі $1,4 \mathrm{мг/кг} \mathrm{незначно} \mathrm{й} \mathrm{недостовірно} \mathrm{збіль-}$ шував тривалість життя на $13,8 \%$, а в дозі 2,8 мг/кг статистично значуще

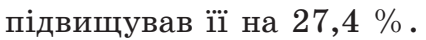

Дозозалежним виявився фригопротекторний ефект селективного інгібітора ЦОГ-2 целекоксибу. У меншій дозі 37 мг/кг дія майже не виявлялась $(4,5 \%)$, у вдвічі вищій $(74$ мг/кг) була максимально виразною в цьому дослідженні: час життя мишей збільшувався на 56,8 \% (p < 0,01 проти показника контрольної патології).

Отже, за результатами скринінгу низки НПЗП на фригопротекторну активність на моделі ГЗО у мишей визначено два препарати-лідери з різним профілем селективності щодо ЦОГ: целекоксиб (74 мг/кг) і диклофенак натрію (14 мг/кг). Вони збільшили час життя тварин 3 експериментальною гострою ХТ більше ніж на $50 \%$, що достовірно перевищує ефект АСК (25 мг/кг). Ці два препарати можна вважати перспективними для подальших поглиблених досліджень фригопротекторної дії.

\section{Висновки}

1. Фригопротекторні властивості нестероїдних протизапальних препаратів за гострого загального охолодження суттєво відрізняються й не виявляють суворої залежності від селективності щодо ізоформ ЦОГ.

2. Найбільший фригопротекторний ефект у мишей виявлено в целекоксибу (74 мг/кг внутрішньошлунково) та диклофенаку натрію (14 мг/кг).

1. Коптяева Р. Г. Высокоселективный ингибитор циклооксигеназы-2 при отморожении в условиях острой алкогольной интоксикации. Экология человека. 2005. № 12. С. 54-57.

2. Горелик И. Э. Профилактика некроза при отморожениях конечностей в дореактивном и раннем реактивном периодах: автореф. дис. на соискание учен. степени канд. мед. наук: спец. 14.01.17 “Хирургия», 14.03.03 «Патологическая физиология»; Сибирский гос. мед. университет Росздрава. Кемерово, 2010. 23 с. 
3. Бондарєв Є. В., Штриголь С. Ю. Вплив препаратів глюкозаміну та ацетилсаліцилової кислоти на артеріальний тиск і показники ЕКГ за умов експериментальної холодової травми. Фармакологія та лікарська токсикологія. 2017. № 6 (56). С. 31-36.

4. Imray C., Grieve A., Dhillon S. Cold damage to the extremities: frostbite and non-freezing cold injuries. Postgraduate medical journal. 2009. № 85. P. 481-488.

5. Wilderness Medical Society Practice Guidelines for the Prevention and Treatment of Frostbite: 2014 Update. S. E. McIntosh, M. Opacic, L. Freer et al. Wilderness \& Environmental Medicine. 2014. № 2 (22). P. $156-166$.

6. Sachs C., Lehnhardt M., Daigeler A. The Triaging and Treatment of Cold-Induced Injuries. Deutsches Arzteblatt International. 2015. № 112. P. 741-748.

7. Патент № 2270013, RU, MПК А61K 31/5415 (2006.01), A61P 31/00 (2006.01). Профилактическое и лечебное средство при сочетанной алкогольно-холодовой травме. Коптяева Р. Г., Назаренко Н. А., Леонтьев В. Я., Сидоров П. И. Патентообладатель Северный государственный медицинский университет. № 2004107203/15; заявл. 10.03.04; опубл. 20.02.06, Бюл. № 5.

8. Бондарєв Є. В. Дослідження глюкозаміну гідрохлориду як засобу фригопротекторної дії при поєднаній алкогольно-холодовій травмі. Фармацевтичний часопис. 2012. №3. С. 140-142.

9. Бондарев E. В. Влияние глюкозамина гидрохлорида и ацетилсалициловой кислоты на показатели углеводного обмена при острой холодовой травме у крыс. Оңтүстік Қазақстан мемлекеттік фармацевтика академия сының хабаршысы. 2015. № 1 (70). С. 2-7.

10. Бондарев Е. В., Штрыголь С. Ю. Антигипотермические и антиоксидантные свойства глюкозамина гидрохлорида и ацетилсалициловой кислоты в условиях острой холодовой травмы. Вестник фармации. 2016. № 3 (73). С. 92-97.

11. Назаренко Н. А. Эффективность нестероидных противовоспалительных средств для профилактики и лечения холодовой травмы: автореф. дис. на соискание учен. степени докт. мед. наук: спец. 05.26.02 «Безопасность в чрезвычайных ситуациях», 14.00.25 «Фармакология, клиническая фармакология»; Северный гос. мед. университет МЗ РФ. Архангельск, 2001. $38 \mathrm{c}$.

12. Холодова травма: доклінічне вивчення лікарських препаратів з фригопротекторними властивостями: методичні рекомендації. Є. В. Бондарєв, С. Ю. Штриголь, С. М. Дроговоз [та ін.]. Харків, 2018. 35 с.

13. Guidance for Industry Estimating the Maximum Safe Starting Dose in Initial Clinical Trials for Therapeutics in Adult Healthy Volunteers. URL: https://www.fda.gov/regulatory-information/search-fdaguidance-documents/estimating-maximum-safe-starting-dose-initial-clinical-trials-therapeuticsadult-healthy-volunteers.html.

14. Сергиенко В. И., Бондарева И. Б., Маевский Е. И. Методические рекомендации по статистической обработке результатов доклинических исследований лекарственных средств. Руководство по проведению доклинических исследований лекарственных средств. Часть первая; под ред. А. Н. Миронова. Москва : Гриф и К, 2012. С. 890-940.

\section{І. Г. Капелька, С. Ю. Штриголь \\ Скринінгове дослідження фригопротекторних властивостей нестероїдних протизапальних препаратів за гострого загального охолодження}

В Україні холодові травми (XT) є досить частим явищем. Вони виникають частіше в зимовий час, коли кількість постраждалих сягає понад 12000 осіб. ХТ спостерігається переважно в молодих осіб працездатного віку, супроводжується великим відсотком інвалідизації та значними матеріальними витратами на лікування потерпілих. Більшій частині постраждалих необхідне стаціонарне лікування, смертність перевищує 10 \%. Особливо небезпечною XТ є в умовах війни, оскільки може спричинити до 25 \% санітарних втрат. Значну роль у патогенезі XT відіграють простациклін, простагландин $F_{2 \alpha}$ i тромбоксан $\mathrm{A}_{2}$, що відповідають за розвиток судинних реакцій. 3 урахуванням механізму розвитку XT можна вважати перспективними фригопротекторами нестероїдні протизапальні препарати (НПЗП), які пригнічують синтез простагландинів.

Мета дослідження - порівняти виразність фригопротекторного ефекту низки НПЗП з різною селективністю щодо ЦОГ на моделі гострого загального охолодження (ГЗО).

Роботу виконано на білих мишах обох статей масою 20-24 г. ГЗО моделювали за температури 18 ㄷ. Визначали інтегральний показник фригопротекторної дії - час життя тварин. Використовували неселективні інгібітори ЦОГ - ацетилсаліцилову кислоту (АСК) (Аспірин, таблетки, «Вауег», Німеччина), ібупрофен (Бруфен, порошок, «Abbott», США), мефенамінову кислоту (Мефенамінова кислотаДарниця, таблетки, «Дарниця», Україна), диклофенак натрію (Вольтарен, таблетки, «Novartis», Швейцарія); помірно селективний інгібітор цОГ - мелоксикам (Моваліс, таблетки, «Boehringer Ingelheim», Німеччина); високоселективний інгібітор ЦОГ - целекоксиб (Целебрекс, таблетки, «Pfizer», США), які вводили в різних дозах у шлунок за 30 хв до початку ГЗО.

Визначено два препарати-лідери з різним профілем селективності щодо ЦОГ: целекоксиб (74 мг/кг) і диклофенак натрію (14 мг/кг). Вони збільшили час життя тварин більше ніж на 50 \%, що достовірно 
перевищує ефект АСК (25 мг/кг). Ці два препарати можна вважати перспективними для подальших поглиблених досліджень фригопротекторної дії.

Отже, фригопротекторні властивості НПЗП за ГЗО суттєво відрізняються та не виявляють суворої залежності від селективності щодо ізоформ ЦОГ.

Ключові слова: холодова травма, гіпотермія, нестероїдні протизапальні препарати

\section{И. Г. Капелька, С. Ю. Штриголь}

\section{Скрининговое исследование фригопротекторных свойств нестероидных противовоспалительных препаратов при остром общем охлаждении}

В Украине холодовые травмы (ХT) встречаются довольно часто. Они возникают чаще в зимний период, когда количество пострадавших достигает более 12000 человек. ХТ наблюдаются в основном у молодых людей работоспособного возраста, сопровождаются высоким процентом инвалидизации и значительными материальными затратами на лечение потерпевших. Большей части пострадавших необходимо стационарное лечение, смертность превышает 10 \%. Особенно опасны XT в условиях войны, поскольку могут стать причиной до 25 \% санитарных потерь. Значительную роль в патогенезе XT играют простациклин, простагландин $F_{2 \alpha}$ и тромбоксан $A_{2}$, которые отвечают за развитие сосудистых реакций. С учетом механизма развития XT можно считать перспективными фригопротекторами нестероидные противовоспалительные препараты (НПВП), которые угнетают синтез простагландинов.

Цель исследования - сравнить силу фригопротекторного эффекта ряда НПВП с разной селективностью относительно ЦОГ на модели острого общего охлаждения (ООО).

Работа выполнена на белых мышах обоих полов массой 20-24 г. ООО моделировали при температуре $-18{ }^{\circ} \mathrm{C}$. Определяли интегральный показатель фригопротекторного действия - время жизни животных.

Использовали неселективные ингибиторы ЦОГ - ацетилсалициловую кислоту (АСК) (Аспирин, таблетки, «Bayer», Германия), ибупрофен (Бруфен, порошок, «Abbott», США), мефенаминовую кислоту (Мефенаминовая кислота-Дарница, таблетки, «Дарница», Украина), диклофенак натрия (Вольтарен, таблетки, «Novartis», Швейцария); умеренно селективный ингибитор ЦОГ - мелоксикам (Мовалис, таблетки, «Boehringer Ingelheim», Германия); высокоселективный ингибитор ЦОГ - целекоксиб (Целебрекс, таблетки, «Pfizer», США), которые вводили в желудок за 30 мин до начала ООО в разных дозах.

Определены два препарата-лидеры с различным профилем селективности относительно ЦОГ: целекоксиб (74 мг/кг) и диклофенак натрия (14 мг/кг). Они увеличили время жизни животных с экспериментальной ХТ более чем на 50 \%, что достоверно превышает эффект АСК (25 мг/кг). Эти два препарата можно считать перспективными для дальнейших углубленных исследований фригопротекторного действия.

Таким образом, фригопротекторные свойства НПВП в условиях ООО существенно различаются и не демонстрируют строгой зависимости от селективности относительно изоформ ЦОГ.

Ключевые слова: холодовая травма, гипотермия, нестероидные противовоспалительные препараты

\section{G. Kapelka, S. Yu. Shtrygol'}

\section{The comparative research of frigoprotective properties of nonsteroidal anti-inflammatory drugs on the model of acute general cooling}

Cold traumas (CT) are quite frequent among the population of Ukraine. Its' occurrence grows up in winter, when number of injured reaches more then 12000 people. CT is commonly observed in young people of working age, causes high frequency of disability and requires high costs for treatment. Most of the injured need hospital treatment, mortality is excess $10 \%$ of cases. In conditions of war CT is especially dangerous. It can cause up to $25 \%$ of sanitary losses even in modern armies.

Research as to the pathophysiology of frostbite has revealed notable similarities with the inflammatory processes seen in burn injuries and ischaemia/reperfusion injury. Evidence for the role of tromboxanes and prostaglandins has resulted in a more active approach to the medical treatment of frostbite.

Considering the role of eicosanoids in the development of cold trauma we can assume positive influence of NSAIDs for such pathology.

The aim of the work is to compare the power of frigoprotective effect of NSAIDs with different selectivity to COX using the model of acute general cooling (AGC).

The experiment was carried out using healthy white mice weighing 20-24 g during single day from 12.00 till 18.00 . Mice were put into individual $500 \mathrm{~cm}^{3}$ plastic cages with free access to air. Cages were situated inside the freezer "Nord Inter-300» with transparent top at a temperature of $-18{ }^{\circ} \mathrm{C}$. An integral index of frigoprotective effect was chosen duration of life.

Some NSAIDs were used in the experiment: nonselective inhibitors of COX - acetylsalicylic acid (Aspirin, tablets, «Bayer», Germany), ibuprofen (Brufen, powder, «Abbott», USA), mefenamic acid (Mefenamic acid-Darnitsa, tablets, «Darnitsa», Ukraine), diclofenac sodium (Voltaren, tablets, «Novartis», Switzer- 
land); moderately selective inhibitor of COX - meloxicam (Movalis, tablets, «Boehringer Ingelheim», Germany); highly selective inhibitor of COX - celecoxib (Celebrex, tablets, «Pfizer», USA).

The results of the present study indicated two NSAIDs with significant frigoprotective effect: celecoxib $(74 \mathrm{mg} / \mathrm{kg}$ ) and diclofenac sodium (14 mg/kg). They increased duration of life of the experimental animals under AGC by more than $50 \%$. That is reliably higher than effect of Aspirin ( $25 \mathrm{mg} / \mathrm{kg})$. These two drugs were chosen as a perspective for future in-depth studies of frigoprotective activity.

As a conclusion we can say that frigorprotective properties of NSAIDs are highly different and don't demonstrate strict dependency with level of selectivity to COX; the highest frigoprotective effect were demonstrated by celecoxib (74 mg/kg intragastrically) and diclofenac sodium ( $14 \mathrm{mg} / \mathrm{kg}$ ).

Key words: cold trauma, hypothermia, NSAIDs.

Надійшла: 27 вересня 2019 р.

Прийнята до друку: 16 жовтня 2019 р.

Контактна особа: Штриголь Сергій Юрійович, доктор медичних наук, професор, кафедра фармакології, Національний фармацевтичний університет МОЗУ, буд.12, вул. Куликовська, м. Харків. Тел.: + 3805770630 69. Електронна пошта: farmacol@nuph.edu.ua 